\title{
PROTOTIPE ALAT MONITORING RADIOAKTIVITAS LINGKUNGAN, CUACA DAN KUALITAS UDARA SECARA ONLINE DAN PERIODIK BERBASIS ARDUINO (STUDI KASUS: BATAN PUSPIPTEK SERPONG)
}

\author{
Yudhaniristo $^{1}$, Nenny Anggraini, M.T ${ }^{2}$, Feri Fahrianto, M.Sc ${ }^{3}$ \\ Prodi Teknik Informatika, Fakultas Sains dan Teknologi \\ UIN Syarif Hidayatullah Jakarta \\ 1yudhaniristo@gmail.com
}

\begin{abstract}
ABSTRAK
Kegiatan monitoring lingkungan suatu kawasan yang memiliki fasilitas penelitian perlu dilakukan karena masyarakat disekitarnya perlu mengetahui faktor lingkungan yang bisa mempengaruhi kesehatannya. Salah satu kawasan yang memiliki fasilitas penelitian adalah PUSPIPTEK Serpong, terdapat fasilitas nuklir riset. Fasilitas nuklir ini akan menghasilkan tingkat radioaktivitas selain itu kendaraan truk disekitar kawasan ini akan menghasilkan polusi akibat hasil pembakaran yang tidak sempurna dan bisa mempengaruhi kesehatan masyarakat. Pihak BATAN juga memiliki suatu kegiatan yaitu monitoring lingkungan fasilitas nuklir, kegiatan ini untuk mengetahui kadar radioaktivitas dari fasilitas nuklir lalu informasinya disebarkan ke masyarakat melalui website. Oleh karena itu, penulis menilai perlu membuat suatu alat yang dapat memonitoring lingkungan pada kawasan PUSPIPTEK ini secara online dan periodik. Prototipe alat ini bertujuan memonitoring tingkat radioaktivitas gamma gross, cuaca (suhu, kelembaban, arah kecepatan angin, curah hujan) kualitas udara (gas CO dan Co2), lalu hasil monitoring tersebut dikirim secara langsung dan otomatis dengan ethernet shield ke server. Tingkat radioaktivitas gamma perlu dipantau karena radioaktivitas gamma mempunyai daya tembus yang besar dan bisa mempengaruhi kesehatan sedangkan gas $\mathrm{CO}$ dan $\mathrm{CO} 2$ berbahaya bagi kesehatan karena tidak bisa dirasakan oleh indera manusia. Melalui alat ini diharapkan kawasan puspitek bisa memonitoring lingkungan khususnya keadaan tingkat radioaktifitas dan kualitas udara serta bisa menyediakan informasi mengenai keadaan lingkungan PUSPIPTEK pada website yang telah tersedia.
\end{abstract}

Kata Kunci: Alat Monitoring Lingkungan, Radioaktivitas,Radiasi, Kualitas Udara, Arduino, Online.

\section{Pendahuluan}

\subsection{Latar Belakang}

Pencemaran lingkungan disuatu kota atau kawasan merupakan salah satu masalah yang kerap muncul. Menurut Undang-undang Pokok Pengelolaan Lingkungan Hidup No. 4 Tahun 1982, polusi atau pencemaran lingkungan adalah masuknya atau dimasukkannya makhluk hidup, zat energi, dan atau komponen lain ke dalam lingkungan, atau berubahnya tatanan lingkungan oleh kegiatan manusia atau oleh proses alam sehingga kualitas lingkungan turun sampai ke tingkat tertentu yang menyebabkan lingkungan menjadi kurang atau tidak dapat berfungsi lagi sesuai dengan peruntukannya.

Macam-macam pencemaran dapat dibedakan berdasarkan pada tempat terjadinya, macam bahan pencemarnya, dan tingkat pencemaran. Menurut tempat terjadinya, pencemaran dapat digolongkan menjadi tiga, yaitu pencemaran udara, air, dan tanah. Untuk pencemaran udara dapat berupa gas dan partikel. Contohnya sebagai berikut.
1. Gas $\mathrm{H}_{2} \mathrm{~S}$. Gas ini bersifat racun, terdapat di kawasan gunung berapi, bisa juga dihasilkan dari pembakaran minyak bumi dan batu bara.

2. Gas $\mathrm{CO}$ dan $\mathrm{CO}_{2}$. Karbon monoksida (CO) tidak berwarna dan tidak berbau, bersifat racun, merupakan hasil pembakaran yang tidak sempurna dari bahan buangan mobil dan mesin letup. Gas $\mathrm{CO}_{2}$ dalam udara murni berjumlah $0,03 \%$. Bila melebihi toleransi dapat mengganggu pernapasan. Selain itu, gas $\mathrm{CO}_{2}$ yang terlalu berlebihan di bumi dapat mengikat panas matahari sehingga suhu bumi panas. Pemanasan global di bumi akibat $\mathrm{CO}_{2}$ disebut juga sebagai efek rumahkaca.

3. Batu bara yang mengandung sulfur melalui pembakaran akan menghasilkan sulfur dioksida. Sulfur dioksida bersama dengan udara serta oksigen dan sinar matahari dapat menghasilkan asam sulfur. Asam ini membentuk kabut dan suatu saat akan jatuh sebagai hujan yang 
disebut hujan asam. Hujan asam dapat menyebabkan gangguan pada manusia, hewan, maupun tumbuhan. Misalnya gangguan pernapasan, perubahan morfologi pada daun, batang, dan benih.

Sumber polusi udara lain dapat berasal dari radiasi bahan radioaktif, misalnya, nuklir. Setelah peledakan nuklir, materi radioaktif masuk ke dalam atmosfer dan jatuh di bumi. materi radioaktif ini akan terakumulusi di tanah, air, hewan, tumbuhan, dan juga pada manusia. Efek pencemaran nuklir terhadap makhluk hidup, dalam taraf tertentu, dapat menyebabkan mutasi, berbagai penyakit akibat kelainan gen, dan bahkan kematian.

Suatu Kota atau daerah yang memiliki fasilitas nuklir baik itu untuk keperluan pembangkit tenaga listrik tenaga Nuklir (PLTN) ataupun untuk kepentingan penelitian, maka kota atau kawasan tersebut harus memiliki alat atau sistem pendeteksi untuk mendeteksi, mengukur dan memonitoring tingkat radiasi karena radiasi tersebut bisa berpotensi meningkatkan pencemaran udara pada kawasan tersebut.

Alasan mendasar perlunya alat monitoring lingkungan fasilitas nuklir ini karena di Indonesia, keamanan dan keselamatan suatu kota atau kawasan yang memiliki fasilitas nuklir diatur oleh peraturan pemerintah nomor 33 tahun 2007 tentang keselamatan radiasi pengion dan keamanan sumber radioaktif pada BAB satu pasal satu yang berbunyi "Keselamatan Radiasi Pengion yang selanjutnya disebut Keselamatan Radiasi adalah tindakan yang dilakukan untuk melindungi pekerja, anggota masyarakat dan lingkungan hidup dari bahaya radiasi".

Peraturan lain yang mengatur tentang keamanan fasilitas nuklir, dibuat oleh salah satu pihak atau badan nuklir di Indonesia yaitu BATAN yang mempunyai Pedoman Keselamatan dan Proteksi Radiasi Kawasan Nuklir Serpong. Pada pedoman tersebut terdapat peraturan mengenai pemantauan radiologi lingkungan yang sesuai dengan Keputusan Kepala BATAN No.392/KA/XI/2005 tentang Organisasi dan Tata Kerja BATAN.

Selain perlunya mengukur tingkat radiasi pada suatu kota atau kawasan (jika ada fasilitas nuklirnya), perlu juga dilakukan pengukuran dan momonitoring kualitas udaranya, ini seperti tercantum dalam Peraturan Menteri Negara Lingkungan Hidup mengenai Pedoman Pelaksanaan Program Adipura pada pasal satu poin satu yang berbunyi "Program Adipura adalah program kerja Kementerian Lingkungan Hidup, yang berlingkup nasional dalam rangka mewujudkan kabupaten/kota yang berwawasan lingkungan menuju pembangunan yang berkelanjutan.", lalu pada poin dua "Kabupaten/kota berwawasan lingkungan adalah kabupaten/kota yang pembangunannya memperhatikan dan mempertimbangkan keselarasan antara fungsi lingkungan hidup, sosial dan ekonomi yang mendukung pembangunan yang berkelanjutan.”.

Peraturan pemerintah Mengenai kualitas udara pada suatu kota terdapat pada pasal satu poin 5 yaitu "Pengendalian pencemaran udara adalah upaya pencegahan dan/atau penanggulangan pencemaran udara serta pemulihan mutu udara." Dan pada poin tujuh yaitu "Evaluasi kualitas udara kota adalah pengujian dan monitoring terhadap pelaksanaan upaya pengendalian pencemaran udara, baik upaya pencegahan maupun upaya penanggulangan pencemaran udara dari emisi dan kebisingan kendaraan bermotor di suatu perkotaan".

Setelah melihat dan mempelajari beberapa peraturan mengenai keamanan radiasi dan polusi udara, Maka penulis berpendapat bahwa perlu dilakukannya penilitian untuk membuat suatu alat yang mampu mendeteksi, mengukur dan memonitoring tingkat polusi udara serta radiasi pada kawasan atau kota yang memiliki fasilitas nuklir.

Berdasarkan observasi, pihak BATAN yang memiliki fasilitas nuklir riset, fasilitas tersebut contohnya untuk bidang kesehatan, selain itu kawasan tersebut juga terdapat fasilitas industri yang biasanya di lalui kendaraan besar seperti truk. Fasilitas nuklir ini akan menghasilkan tingkat radioaktivitas selain itu kendaraan truk disekitar kawasan ini akan menghasilkan polusi akibat hasil pembakaran yang tidak sempurna dan bisa mempengaruhi kesehatan masyarakat.

Berdasarkan observasi, peraturan dan hasil wawancara yang telah diuraikan, maka penulis berpendapat perlunya dibuat suatu alat untuk monitoring tingkat radiasi nuklir serta kualitas udara pada suatu kota atau kawasan dan alat tersebut mampu menyediakan informasi mengenai keadaan lingkungannya.

\subsection{Perumusan Masalah}

Adapun rumusan masalah dari tugas akhir ini adalah bagaimana membuat sebuah sistem prototipe alat yang mampu memonitoring tingkat pencemaran udara baik kualitas udara maupun cuaca serta tingkat radioaktivitas gamma gross secara online dan periodik berdasarkan standar dan kriteria yang berlaku.

\section{TINJAUAN PUSTAKA}

\subsection{Definisi Prototipe}

Prototyping menurut Houde dan Hill merupakan salah satu metode pengembangan perangkat lunak yang banyak digunakan. Dengan metode Prototyping ini pengembang dan pelanggan 
dapat saling berinteraksi selama proses pembuatan sistem. Sering terjadi seorang pelanggan hanya mendefiinisikan secara umum apa yang dikehendakinya tanpa menyebutkan secara detail output apa saja yang dibutuhkan, pemrosesan dan datadata apa saja yang dibutuhkan. Sebaliknya disisi pengembang kurang memperhatikan efesiensi algoritma, kemampuan sistem operasi dan interface yang menghubungkan manusia dan komputer. Untuk mengatasi ketidaksesuaian antara pelanggan dan pengembang, maka harus dibutuhkan kerjasama yang baik diantara keduanya sehingga pengembang akan mengetahui dengan benar apa yang diinginkan pelanggan dengan tidak mengesampingkan segi-segi teknis dan pelanggan akan mengetahui proses-proses dalam menyelesaikan sistem yang diinginkan. Dengan demikian akan menghasilkan sistem yang sesuai dengan jadwal waktu penyelesaian yang telah ditentukan.

\subsection{Efek Radiasi Terhadap Manusia}

Jika radiasi mengenai tubuh manusia, ada dua kemungkinan yang dapat terjadi: berinteraksi dengan tubuh manusia atau hanya melewati saja. Jika beriteraksi, radiasi dapat mengionisasi atau dapat pula mengeksitasi atom. Setiap terjadi proses ionisasi atau eksitasi, radiasi akan kehilangan sebagian energinya. Energi radiasi yang hilang akan menyebabkan peningkatan temperature (panas) pada bahan (atom) yang beinteraksi dengan radiasi tersebut. Dengan kata lain, semua energi radiasi yang terserap di jaringan biologis akan muncul sebagai panas melalui peningkatan vibrasi (getaran) atom dan struktur molekul. Ini merupakan awal dari perubahan kimiawi yang kemudian dapat mengakibatkan efek biologis yang merugikan.

\subsection{Definisi Online}

Secara umum, sesuatu dikatakan online adalah bila ia terkoneksi atau terhubung dalam suatu jaringan ataupun sistem yang lebih besar. Beberapa arti kata online lainnya yang lebih spesifik yaitu :

Dalam percakapan umum, jaringan atau network yang lebih besar dalam konteks ini biasanya lebih mengarah pada internet, sehingga online lebih pada menjelaskan status bahwa ia dapat diakses melalui internet.

Secara lebih spesifik dalam sebuah sistem yang terkait pada ukuran dalam satu aktivitas tertentu, sebuah elemen dari sistem tersebut dikatakan online jika elemen tersebut beroperasional. Sebagai contoh, Sebuah instalasi pembangkit listrik dikatakan online jika ia dapat menyediakan listrik pada jaringan elektrik.

\subsection{Waktu Respon Sistem}

Saran dasar mengenai waktu respon telah hampir sama selama 30 tahun terakhir [Miller 1968; Card dkk. 1991] :

a. 0,1 detik adalah tentang batas untuk pengguna merasakan cepatnya suatu proses dari suatu sistem. Artinya tidak ada timbal balik dari sistem melainkan hanya menampilkan hasil.

b. 1,0 detik adalah tentang batas untuk aliran berpikir pengguna untuk tetap tidak terganggu, meskipun pengguna akan melihat penundaan. Biasanya, tidak ada timbal balik khusus diperlukan selama penundaan lebih dari 0,1 tetapi kurang dari 1,0 detik, pengguna tidak kehilangan perasaan yang beroperasi secara langsung pada data.

c. 10 detik adalah tentang batas untuk menjaga perhatian pengguna terfokus pada dialog. Untuk penundaan lagi, pengguna akan ingin untuk melakukan tugas lain sementara menunggu komputer untuk menyelesaikan, sehingga mereka harus diberi timbal balik yang menunjukkan saat komputer mengharapkan untuk dilakukan. Timbal balik selama penundaan itu sangat penting jika waktu respon mungkin akan sangat bervariasi, karena pengguna akan tidak tahu apa yang diharapkan.

\subsection{Mikrokontroler Arduino}

Arduino adalah suatu mikrokontroler kecil yang berisi semua komponen komputer dan memiliki keukatan yang tidak begitu besar.Tapi dengan Arduino yang murah tersebut, kita dapat membuat alat - alat yang sangat menarik. Arduino merupakan chip berwarna hitam yang mempunyai 28 kaki yang disebut ATmega168. Agar mikrokontroler Arduino dapat berkerja dengan baik dan dapat berkomunikasi dengan komputer, seluruh komponen - komponen yang dibutuhkan harus diletakkan pada tempatnya.

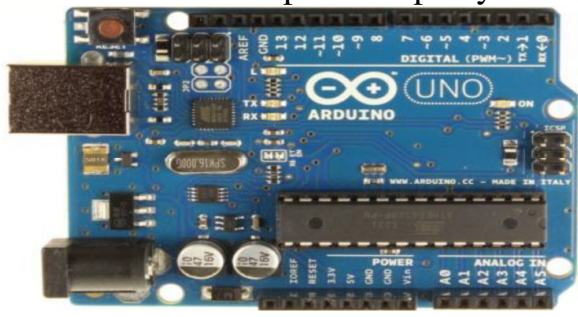

Gambar 2.1. Mikrokontroler Arduino

\section{METODE PENELITIAN}

\subsection{Observasi/Studi Lapangan}

Penulis melakukan pengamatan atau observasi langsung pada kawasan BATAN PUSPIPTEK, yaitu tepatnya pada bidang PRFN (Pusat Rekayasa Fasilitas Nuklir). Penulis mengamati dan mencari informasi bagaimana pihak PRFN melakukan deteksi dan monitoring terhadap fasilitas nuklir, sensor atau 
komponen apa saja yang akan digunakan, apa standar yang dipakai untuk melakukan deteksi tersebut serta data atau info apa yang akan dihasilkan dari proses deteksi dan monitoring yang akan dilakukan. Observasi dilaksanaan pada 25 Agustus.

\subsection{Wawancara}

Penulis melakukan wawancara secara langsung dengan pihak terkait yang ada di kantor PRFN BATAN yaitu Bapak Dr. I Putu Susila selaku peneliti di bidang Instrumensi PRFN BATAN. Wawancara yang dilakukan mengenai perlunya dibuat suatu alat atau perangkat yang mampu mendeteksi dan memonitoring tingkat radiasi serta kualitas udara pada fasilitas nuklir yang ada di kawasan BATAN PUSPIPTEK.

\subsection{Metode Pengembangan Alat}

Pada penelitian ini, penulis menggunakan metode prototyping. Menurut Houde dan Hill, dengan metode Prototyping ini pengembang dan pelanggan dapat saling berinteraksi selama proses pembuatan system. Sering terjadi seorang pelanggan hanya mendefiinisikan secara umum apa yang dikehendakinga tanpa menyebutkan secara detail output apa saja yang dibutuhkan, pemrosesan dan datadata apa saja yang dibutuhkan. Sebaliknya disisi pengembang kurang memperhatikan efesiensi algoritma, kemampuan system operasi dan interface yang menghubungkan manusia dan komputer. Untuk mengatasi ketidaksesuaian antara pelanggan dan pengembang, maka harus dibutuhkan kerjasama yang baik diantara keduanya sehingga pengembang akan mengetahui dengan benar apa yang diinginkan pelanggan dengan tidak mengesampingkan segi-segi teknis dan pelanggan akan mengetahui proses-proses dalam menyelesaikan system yang diinginkan. Dengan demikian akan menghasilkan system yang sesuai dengan jadwal waktu penyelesaian yang telah ditentukan.

Berikut tahapan yang digunakan dalam metode prototyping (Roger S.Pressman, 2001:30):

a. Tahap Pengumpulan Kebutuhan

Prototyping dimulai degnan pengumpulan persyaratan pembangun dan bertemu pelanggan dan menentukan tujuan keseluruhan untuk perangkat/alat, mengidentifikasi persyaratan apapun yang diketahui dan area garis besar dimana definisi lebih lanjut itu diharuskan. Desain berfokus pada representasi dari aspek-aspek perangkat lunak yang akan dilihat oleh pelanggan atau pengguna (misalnya, pendekatan input dan format output) (Presman, 2001:30).

Pada tahapan pengumpulan kebutuhan ini, penulis melakukan pengumpulan data dengan cara observasi dan wawancara terhadap pihak terkait PRFN
BATAN serta studi pustaka. Dari hasil pengumpulan data tersebut, penulis mendapatkan data mengenai sensor, komponen, tools yang akan digunakan, data mengenai standar pengukuran tingkat radiasi serta kualitas udara, lalu data mengenai desain dan proses pembuatan alatnya.

Tahap pengumpulan kebutuhan ini akan terus berjalan selama masih membangun prototipe sampai tahap pengujian alatnya.

b. Tahap Membangun Prototipe

Peneliti melakukan perancangan sistem deteksi dengan menggunakan metode Prototyping. Model prototipe dimulai dengan pengumpulan persyaratan. pembangun dan bertemu pelanggan dan menentukan tujuan keseluruhan untuk perangkat lunak, mengidentifikasi persyaratan apapun yang diketahui, dan area garis besar dimana definisi lebih lanjut itu diharuskan. Desain berfokus pada representasi dari aspek-aspek perangkat lunak yang akan dilihat oleh pelanggan / pengguna (misalnya, pendekatan input dan format output). (Pressman,2001:30)

Dalam tahap membangun protoipe ini, peneliti membuat flowchart dari setiap sensor yang berhubungan dengan Arduino Uno. Selain itu, peneliti juga membuat blok diagram untuk prototipe alat monitoring lingkungan ini, dimulai dari Arduino mengontrol sensor-sensor yang melakukan proses deteksi, lalu mengirimkan hasil deteksi tersebut ke database server dengan modul Ethernet shield.

c. Tahap Pengkodean Sistem

Pada tahap ini, peneliti menulis dan membuat kode program dengan IDE (Integrated Development Environment) Arduino versi 1.5.6-r2 BETA menggunakan bahasa pemrograman $\mathrm{C}$. Peneliti juga memanfaatkan library untuk setiap sensor yang di unduh dari internet, khususnya yang tersedia pada situs www.github.com. Penggunaan library ini sangat membantu untuk pembuatan program pada setiap sensor.

Peneliti juga menggunakan bahasa pemrograman web dari sisi server (server side) yaitu bahasa pemrograman PHP, PHP ini digunakan untuk membuat program yang berfungsi mengambil data yang dikirim dari alat monitoring lingkungan (Arduino + sensor + Ethernet shield) lalu memasukkan data tersebut ke database monitoring lingkungan.

d. Tahap Pengujian Alat

Dalam tahap pengujian alat, peneliti menggunakan cara black box testing, yaitu prototipe alat monitoring lingkungan akan diuji dengan berfokus pada fungsi-fungsi yang harus memenuhi syarat kebutuhan. Pada tahap ini alat akan diuji dari tingkat kepekaan sensor, kode program (source code) serta kemampuan alat melalui modul Ethernet shield untuk 
mengirim data hasil monitoring lingkungan dari sensor ke database yang ada pada komputer server secara langsung dan periodik.

\section{HASIL DAN PEMBAHASAN}

\subsection{Analisa Kebutuhan Hardware}

Dalam pembuatan prototipe monitoring lingkungan fasilitas nuklir ini, peneliti membutuhkan beberapa perangkat keras seperti mikrokontroler maupun komponen sensor-sensor untuk mendeteksi dan memonitoring kondisi radiasi, cuaca dan kualitas udara. Pemilihan spesifikasi hardware sangatlah penting agar nantinya prototipe monitoring lingkungan fasilitas nuklir ini dapat berjalan dengan baik sesuai kebutuhan user.

Tabel 4.1. Daftar Kebutuhan Hardware

\begin{tabular}{|c|c|c|c|}
\hline No & $\begin{array}{l}\text { Komponen } \\
\text { Elektronik }\end{array}$ & Jumlah & Kegunaan \\
\hline 1. & $\begin{array}{l}\text { Mikrokontroler } \\
\text { Arduino Uno }\end{array}$ & 1 & $\begin{array}{l}\text { Mengolah data yang } \\
\text { didapat dari } \\
\text { komponen } \\
\text { pendukung lainnya }\end{array}$ \\
\hline 2. & $\begin{array}{l}\text { Sensor radiasi } \\
\text { (Ludlum } \\
\text { Scintillator } \\
\text { NaTI) }\end{array}$ & 1 & $\begin{array}{l}\text { Untuk mendeteksi } \\
\text { keberada-an radiasi } \\
\text { gamma }\end{array}$ \\
\hline 3. & $\begin{array}{l}\text { Sensor DHT } 21 \\
\text { (suhu dan } \\
\text { kelembaban } \\
\text { udara) }\end{array}$ & 1 & $\begin{array}{lr}\text { Untuk mendeteksi } \\
\text { kondisi suhu serta } \\
\text { kelembaban udara } \\
\text { disekitar. }\end{array}$ \\
\hline 4. & $\begin{array}{l}\text { Sensor angin } \\
\text { (kecepatan dan } \\
\text { arah angin serta } \\
\text { curah hujan) }\end{array}$ & 1 & $\begin{array}{l}\text { Untuk mengukur } \\
\text { kecepatan, arah angin } \\
\text { serta curah hujan }\end{array}$ \\
\hline 5. & $\begin{array}{l}\text { Sensor Gas CO } \\
\text { (TGS2442) }\end{array}$ & 1 & $\begin{array}{l}\text { Untuk mendeteksi } \\
\text { keberada-an gas CO }\end{array}$ \\
\hline 6. & $\begin{array}{l}\text { Sensor Gas } \\
\text { CO2 } \\
\text { (TGS4161) }\end{array}$ & 1 & $\begin{array}{l}\text { Untuk mendeteksi } \\
\text { keberada-an gas } \mathrm{CO} 2\end{array}$ \\
\hline 7. & Ethernet Shield & 1 & $\begin{array}{lr}\text { Untuk komunikasi } \\
\text { data } & \text { dari } \\
\text { sensor+arduino } & \text { ke } \\
\text { server } & \end{array}$ \\
\hline 8. & Kabel Jumper & 1 set & $\begin{array}{l}\text { Membantu } \\
\text { mengalirkan data dan } \\
\text { arus listrik dari } \\
\text { mikro-kontroler ke } \\
\text { perangkat pendukung } \\
\text { lainnya. }\end{array}$ \\
\hline 9. & Breadboard & 1 & $\begin{array}{l}\text { Sebagai media untuk } \\
\text { merangkai } \\
\text { komponen }\end{array}$ \\
\hline
\end{tabular}

\subsection{Analisa Kebutuhan Software}

Agar prototipe alat monitoring lingkungan fasilitasi nuklir ini bisa berjalan dengan baik yang perlu diperhatikan bukan hanya dari segi hardware saja, tetapi juga diperlukan perangkat lunak (software). Software ini dibutuhkan karena perangkat mikronkontroler tidak akan bekerja sesuai dengan kebutuhan yanpa adanya instruksi-instruksi program yang telah ditanamkan kedalam mikrokontroler tersebut. Dengan adanya instruksi-instruksi program yang telah ditanamkan di dalam alat tersebut, mikrokontroler dapat menjalankan fungsinya yaitu memonitoring kondisi radiasi, cuaca serta kualitas udara pada fasilitas nuklir lalu meneruskan informasi hasil monitoring tersebut ke dalam website.

Oleh karena itu, penulis menggunakan perangkat lunak yaitu IDE Arduino 1.5.6-r2 BETA. Perangkat llunak ini sangat mudah digunakan karena sangat kompatibel dengan berbagai jenis Arduino termasuk Arduino UNO yang akan digunakan oleh peneliti serta memiliki library lengkap untuk mendukung komponen-komponen yang akan digunakan.

\subsection{Membangun Prototipe}

Membangun prototipe didefinisikan sebagai perancangan sistem yang dibuat sebagai tahap awal dalam membuat suatu prototipe alat sebelum diubah ke dalam bentuk kode. Perancangan alat ini fokus pada segi teknis atau implementasi sebuah sistem.

Untuk memudahkan proses pembuatan prototipe dan cara kerja masing-masing modul sensor maka penulis membuat suatu flowchart atau alur kerja dari prototipe alat terlebih dahulu. Hal ini sangat penting, karena dalam pembuatan suatu alat setiap rangkaian saling berhubungan dan mempengaruhi kinerja alat lainnya sehingga hasil yang didapat sesuai dengan keinginan dan teori yang berlaku. Gambar flowchart sistem rancangan alat yang akan dibuat secara utuh dapat dilihat seperti gambar berikut. 


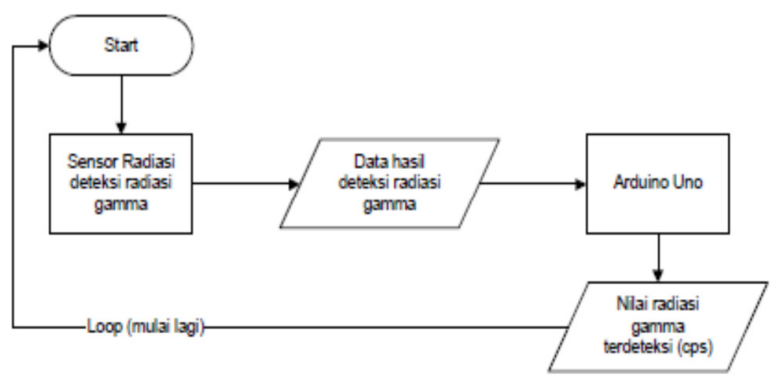

kadar gas $\mathrm{CO}$ dan $\mathrm{CO} 2$ lalu mengirimkan sinyal ke Arduino Uno.

4. Ethernet Shield berfungsi untuk mengirimkan informasi hasil monitoring dari alat monitoring lingkungan ke database.

\subsection{Pengkodean Sistem}

Pada tahap ini, peneliti membuat kode program untuk merealisasikan rancang bangun prototipe yang sebelumnya telah dibuat. Peneliti membuat dua kode program yiatu untuk alat monitoring lingkungannya dengan IDE Arduino dengan bahasa pemrograman C serta kode program untuk mengambil dan mengirim data hasil monitoring ke server dengan bahasa pemrograman PHP. Kode program pada alat yang dibuat terdiri dari beberapa fungsi, yaitu:

1. Fungsi untuk mendeteksi tingkat radioaktivitas gamma gross,

2. Fungsi untuk mendeteksi kondisi suhu dan kelembaban udara,

3. Fungsi untuk mendeteksi arah dan kecepatan angin serta curah hujan,

4. Fungsi untuk mengirim data monitoring ke server.

\subsection{Pengujian Alat}

a. Pengujian sensor pendeteksi radioaktivitas (Ludlum Scintillator) dan suhu serta kelembaban udara (DHT21).

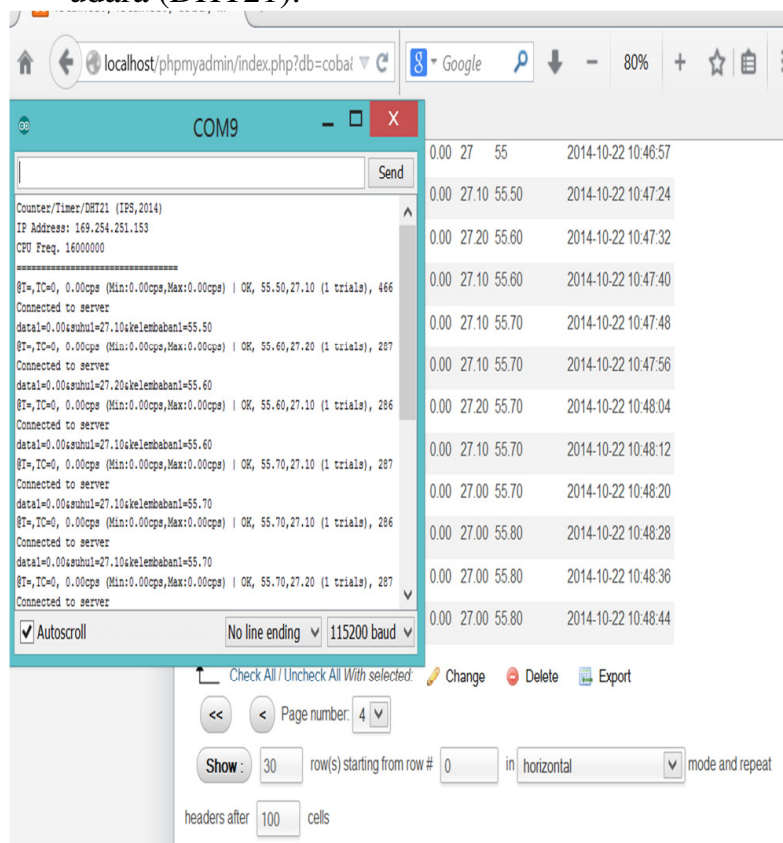

Gambar 4.2. Hasil Deteksi Radioaktivitas, Suhu, Kelembaban

Pada gambar diatas adalah hasil dari pengukuran radioaktivitas gamma gross dari Cessium 127 serta pengukuran suhu dan kelembaban udara, data pengukuran tersebut juga dikirim secara real time ke database. Untuk data radioaktivitas satuannya berupa 
cps (count per second), suhu dalam derajat Celcius dan kelembaban dalam persen. Pada pengujian tersebutc. alat bekerja setiap delapan detik.

b. Hasil data pada database

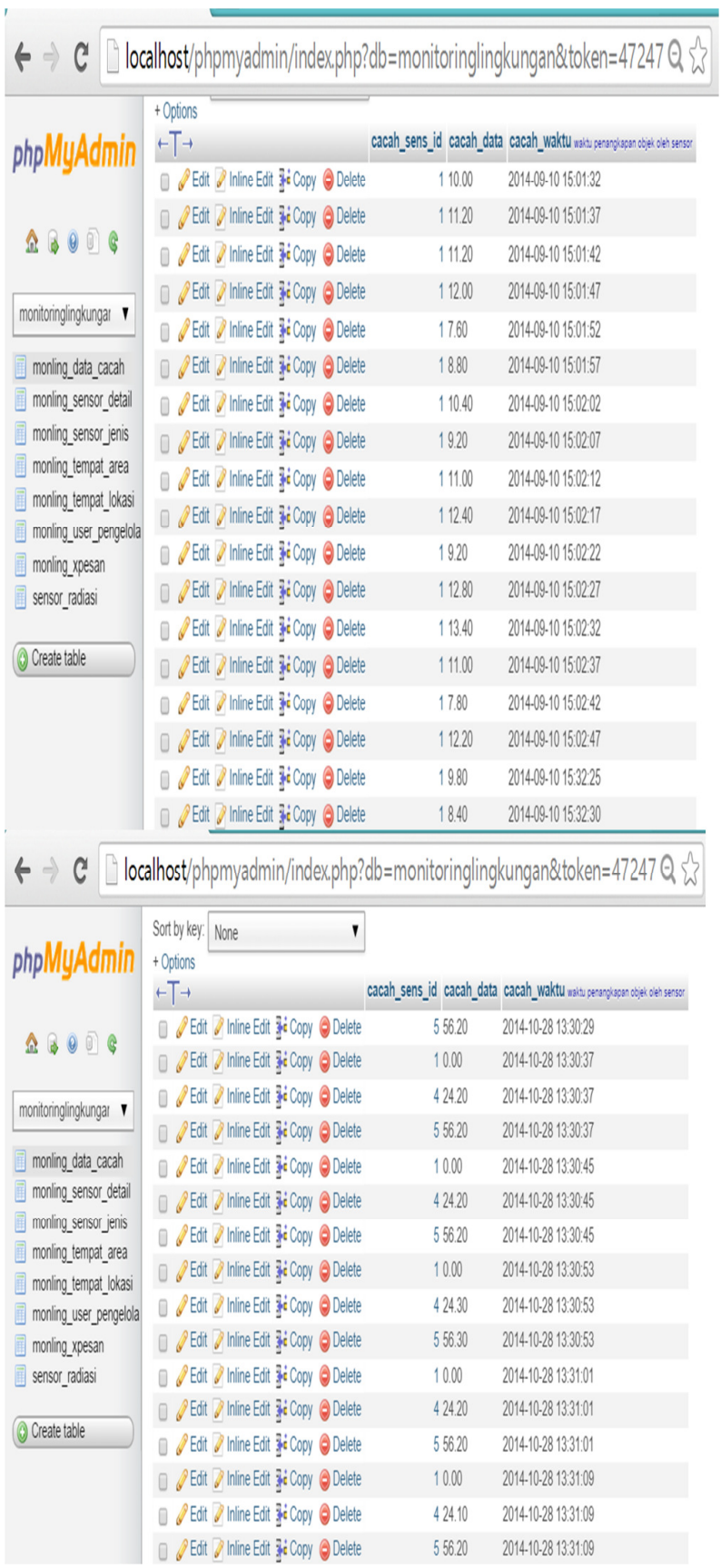

Gambar 4.3. Data Monitoring

Pada gambar diatas merupakan data dari sensor deteksi radioaktivitas yang dikirim setiap lima detik dan delapan detik. Kolom cacah_sens_id merupakan kolom untuk data dari setiap sensor. Kolom cacah_data berisi data dari sensor, lalu kolom cacah waktu merupakan kolom yang menunjukkan waktu dari data hasil monitoring tersebut masuk ke database.
Pengujian integerasi dan pengiriman data ke database

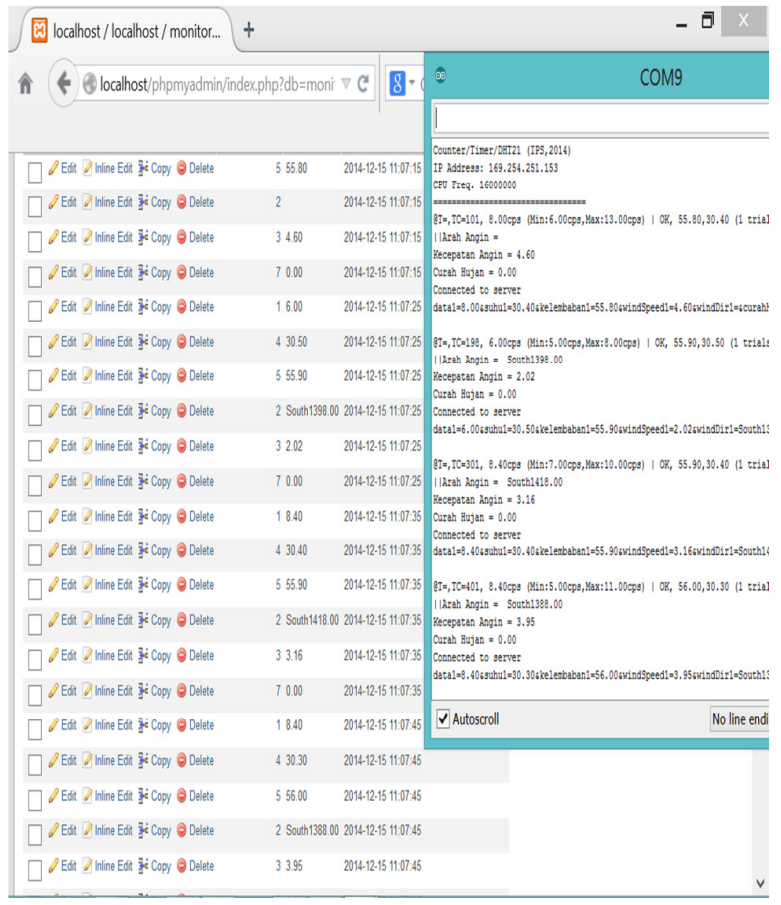

Gambar 4.4. Pengujian Integrasi Prototipe

Pengujian integerasi dan pengiriman data ke database ini dilakukan setiap 10 detik, bisa dilihat dari jeda waktunya, misal, pengiriman data pertama dilakukan pada menit ke 7 detik ke 15 lalu pengiriman kedua pada menit ke 7 detik ke25 dan seterusnya. Pada kolom pertama adalah kolom untuk id sensor, yaitu:

1. Id sensor 1 untuk data radiasi

2. Id sensor 2 untuk data arah angin

3. Id sensor 3 untuk data kecepatan angin

4. Id sensor 4 untuk data suhu udara

5. Id sensor 5 untuk data kelembaban

6. Id sensor 7 untuk data curah hujan

\section{PENUTUP}

Berikut dibawah ini adalah beberapa poin kesimpulan yang penulis uraikan berdasarkan penelitan yang telah dilakukan, adalah sebagai berikut:

Proses monitoring lingkungan dilakukan secara online dan periodik selama 10 detik berdasarkan (Miller, 1968), yaitu monitoring terhadap radioaktivitas dari gamma gross, cuaca (suhu, kelembaban, angin, curah hujan) serta kualitas udara (deteksi gas $\mathrm{CO}$ dan $\mathrm{CO} 2$ ) dengan sensor-sensor yang dihubungkan dengan modul mikrokontroler Arduino Uno. Arduino mampu mengontrol kerja sensor-sensor secara bersamaaan dalam satu waktu. Data hasil monitoring kemudian di kirim ke server menggunakan protokol HTTP melalui modul Ethernet. 


\section{DAFTAR PUSTAKA}

[1] Arduino. 2010.Beginning Arduino. [Online] Tersedia : www.arduino.cc.

[2]Djuandi,Feri.2011."Pengenalan Arduino".[pdf].http://www.tobuku.com

[3]www.batan.go.id/pusdiklat/elearning/proteksiradias i/pengenalan_radiasi/1-1.html

[4] Bukit, Benar. Rifai, A. Budi Jos. 2011. Rancangan Perangkat Lunak Monitoring Radiaoaktivitas Lingkungan Instalasi Nuklir. Serpong: PRFNBATAN PUSPIPTEK

[5] Sumaryono, Sujoko. Risanuri, Hidayat. Shobari, Ikhsan. Pemantauan Paparan Radiasi Lingkungan Terpadu Dengan Komunikasi GSM/GPRS. UGM: Yogyakarta.

[6] Hari Sasongko, Bagus.2012.Pemrograman Mikrokontroler dengan Bahasa C.ANDI:Yogyakarta

[7] Houde,Stephanie \& Hill,Charles. 2004. What do Prototypes Prototype? USA: Apple Computer,Inc.

[8] Hakim, Lukmanul. 2009. Trik Rahasia Master PHP Terbongkar Lagi. Yogyakarta: Lokomedia.
[9] Hariyanto, Bambang. 2004. Sistem Manajemen Basis Data : Pemodelan, Perancangan, dan Terapannya. Bandung : Informatika.

[10]Jogianto, HM. 2005. Analisis dan Desain Sistem Informasi : Pendekatan Terstruktur Teori dan Praktek Aplikasi Bisnis. Yogyakarta: Andi.

[11]Sridadi, Bambang, Ir.,Msc. 2010. Real Time Sistem. Bandung : Informatika.

[12]Hariyanto, Bambang. 2005. Rational Rose untuk Pemodelan Berorientasi Objek Bandung : Informatika.

[13]Kendall, Kenneth E. dan Kendall, Julie E. 2003. Analisis dan Perancangan Sistem. Jakarta : Pearson Education Asia Pte. Ltd dan PT. Prenhallindo.

[14]Ladjamudin, Albahra. 2005. Analisis dan Desain Sistem Informasi. Yogyakarta Graha Ilmu.

[15]Sridadi, Bambang, Ir.,Msc. 2010. Real Time Sistem. Bandung : Informatika.

[16]Pressman, Roger S.2001."Software Engineering".[pdf]. 